\title{
Oxygen Monitor Subassembly Device
}

National Cancer Institute

\section{Source}

National Cancer Institute. Oxygen Monitor Subassembly Device. NCI Thesaurus. Code C50085.

A sensor and circuit designed to sense the oxygen level in a space, environment, or material, as part of a larger device. 